\title{
LATIN AMERICAN ESSAY: LITERARY CONSTRUCTIONS OF CULTURAL IDENTITY
}

\author{
Freddy Chachagua
}

\begin{abstract}
This article provides a careful look at three essays that deal directly with the relationship between cultural identity and the specificity of the Latin American essay, reviewing and questioning the prevailing understanding of the Latin American essay's origin. This leads to a comprehensive contextualization of works by Inca Garcilaso de la Vega, Domingo Faustino Sarmiento, and José Marti that goes beyond monolithic literary studies.
\end{abstract}

Philosophers such as Hume, Kant, Jefferson, and Hegel seemed to decide that the presence of a written literature was the signal measure of the potential, innate humanity of all non-white people in Western cultures.

So insistent did these racist allegations prove to be, at least from the eighteenth to the early twentieth centuries, that it is fair to describe the subtext of the history of native and black letters as this urge to refute the claim that because blacks [and natives] had no written traditions, they were bearers of an inferior culture. (Gates, 1987)

The theoretical reflections informing this article are derived from an effort to understand the relationship between cultural identity and the specificity of the Latin American essay. The study of the Latin American essay has so far been conducted by a small group of critics and academics. ${ }^{1}$ Attention has been given to major Latin American essayists and to the problems of fitting their work into such established notions as literary periods and signifiers of universal values. $^{2}$ What I criticize in this article is the fact that many of these valuable studies do not address issues of cultural identity and its relationship with the genealogy of the essay. However, I see this article as advancing or complementing those studies, not discounting or displacing them.

The prevailing understanding of the Latin American essay's origin takes Spanish colonialist writings as its point of departure. This construct obviously implies that the history of Latin American societies began with the arrival of the Europeans. It should be noted, however, that this line of thinking denies how Latin America was reinvented by the European imagination. Historically, Latin American high culture has urged mimesis of European discourses, implicitly embracing European styles and concerns as signifiers of universal values. Consequently, Latin American, North American and European élites have denigrated adaptations of European literary forms to local contexts as deviations from the established paradigm. In the case of the essay, they have dismissed as inferior or non-representative writers who do not adhere to the European form. This vision represents a European hegemonic discourse. Thus, the affirmation of cultural identity 
given to the Latin American essay in some of these studies can be seen as an invitation to exclusion and closure.

Notwithstanding this hegemonic position, critics outside of the mainstream identify Africa, Europe, and native America as the three pillars upon which rest the civilization and culture that is peculiar to Latin America. Therefore, any attempt to undervalue either the African or the native component by the European hegemonic perspective would render any study truncated and imperfect. Since Latin American essays reveal a different normative political agenda and social visions, which diverge from European discursive reinventions of this region, I recognize that studies of the origins of the Latin American essay do not have to perpetuate the colonialist legacy.

Having said that, I want to emphasize that the notion of cultural identity that is thematically central to this article is to be understood in a process-oriented and transformative sense. Cultural identity, like the concepts of ethnic identity or gender identity, can be used to distinguish the positive features uniting a number of individuals around something they hold to be a very valuable part of their being. In this case, the values in question refer to a certain cultural heritage to which individuals feel strongly attached by historical and/or affective ties. To speak of a Latin American cultural identity is to define a given system of values intended to preserve and enhance a specific cultural and literary heritage and to promote, within the international community, an outlook favorable to the recognition of the validity and integrity of these values. In the case of the relations between Europe and the United States, on the one hand, and Latin America on the other, to speak of a Latin American identity also refers to a process aimed at rectifying an imbalance of power between Europe and the United States and Latin American countries.

In order to free as much as possible the concept of cultural identity from a dogmatic approach to values, I believe it is important to consider the notion of cultural identity as the result of a collectively interpreted process freely engaged in, and always open to modification or transformation by the members of a cultural community.

The three paradigms used in this article to defend the integrity and specificity of the Latin American essay and culture are: 1) Inca Garcilaso de la Vega's affirmation of the values of the continent's indigenous pre-Columbian heritage, 2) Domingo Faustino Sarmiento's discursive reinvention of South America and, 3) José Marti's notion of hibridez (a cultural and racial complex mixture rooted in the region's history) as an affirmation of a continental Latin American cultural identity.

The first paradigm in which I argue that difference is constitutive of Latin American essays and culture is revealed in Garcilaso de la Vega's cultural critique, which does not limit itself to an inversion of the binary opposition between civilization versus barbarism.

In a situation where the cultural and literary values of the colonizer were clearly dominant and considered superior, "forgetting" the indigenous heritage was a widely adopted strategy on the part of the mestizos in their desire to leave their marginalized condition. At the same time that many mestizos were actively "fforgetting" and being forced to forget their heritage, others, such 
as the Inca Garcilaso de la Vega were reconstructing the pre-Columbian past in a conscious act of remembering, resistance, and criticism of the conquest.

In his Comentarios Reales de los Incas (1609) Garcilaso develops an allegorization of the system that authorizes the writing of a distinctive Latin American tradition as well as cultural identity. Rather than reiterating that the condition of being an "Indian" (and, perhaps, in the last instance a Latin American) corresponds to a lack of letters, his essays suggest a cultural construct that defines being an Indian/Latin American with two traits that would demonstrate their capacity to write their own history. These two traits are:

1) A lack of what the Spaniards defined as "purity of blood" and, 2) an ancient Amerindian oral tradition.

Garcilaso certainly has another important end in mind: to salvage the image of Amerindians by representing them as magnanimous and able in all realms of culture. In fact, it is his subjectivity, his position as an Indian/Latin American that leads him to claim a perspective denied to those who write from the experience of travelling from Europe to America.

In the second paradigm, following independence from Spain in the early nineteenth century, Euro-Latin American élites selected and adapted European discourses on Latin America to their own task of creating autonomous decolonized cultures while retaining European values and white supremacy. I am referring to the political essay Civilización y barbarie: Vida de Juan Facundo Quiroga (1845), by the Argentine Domingo Faustino Sarmiento, which exemplifies the dynamics of criollo self-fashioning, exclusion and contradiction.

Setting aside the Amerindians, Sarmiento presents an official vision of the Pampas and their cultural mixture. European theories of environmental determinism are applied to the mestizo inhabitants of the Pampas, the gauchos. The vast plains of the Argentine interior, argues Sarmiento, lend an "Asiatic" character to human life there.

The principal part of Facundo comprises a historical biography of the provincial caudillo Juan Facundo Quiroga. Through an account of Facundo's life and violent death, Sarmiento explores Argentina's difficulties in consolidating itself as a nation. In Sarmiento's analysis, Facundo's ruthlessness, his conservative authoritarianism, and his reliance on violence and a private army as basic political tools exemplify the "barbarism" that infects Argentine society and obstructs the republican nation-building process. At the same time as he condemns this barbarism, Sarmiento conveys a profound fascination with Facundo as a figure and with the mestizo lifestyle of the interior (where Sarmiento himself grew up). While condenned as backward, the interior provinces, centers of Argentine life under Spanish rule, are simultaneously recognized as a source of authentically Latin American and Argentinean cultural material.

The third way in which difference is also constitutive of Latin American models of cultural identity and literary construction is related to the hybrid nature of the developing societies in the region and the heterogeneous influences they received. In this way of conceptualizing Latin American cultural identity and literature, "difference" is not represented by the indigenous population (the first and most obvious localization of alterity); nor is it represented by the European or North American "Other". (the second form of alterity, particularly prevalent before 
and after the independence movements). Rather, in this third model, difference is located irremediably within Latin American society, and considered constitutive of its identity. Terms such as José María Arguedas' "Indo-América" and José Martís "mestizo América" reveal an attempt to conceive of Latin America culture as well as its literature as hybrid.

"Nuestra América" (1889) reveals a truly authentic Latin American consciousness with respect to the issue of cultural identity. This new and positive view of hibridez expands the libertarian project of Simón Bolívar to a new egalitarian base. On the question of racial difference, Martí held that human beings belong only to one species, humankind. His vision lays the foundation for a new type of hibridez-one determined by the principle of equality.

Regarding the idea on mental emancipation to be achieved by importing European ideas into the region, Martí suggests that "neither the European book nor the Yankee provide the key to the Latin American enigma." (1973, my translation) Referring to Sarmiento's polarization of European civilization and Argentinean/Latin American "barbarism", the Cuban essayist stated, "there is no conflict between civilization and barbarism, only between a false erudition and nature ... the autochthonous mestizo has conquered the exotic criollo" (1973, my translation).

Finally, regarding the denigration of Latin America, he said, "And let the conquered pedant be silent, for there is no fatherland where a man may be prouder than in our painful Latin American republics" (1973, my translation).

Marti's assessment of hibridez is egalitarian and self-assertive. Mestizos, blacks, whites, and Amerindians are equal in that they are all human. From a cultural standpoint, however, it is important to give priority to one's own cultural legacy. In this view, Marti suggests that despite the great value of European classics, it is more important for Latin Americans to know their own culture and history: "Our Greece is more important than the Greece that is not ours" (1973, my translation). Marti's perspective elevates the notion of hibridez by making all races synonymous with humanity. At the same time he also elevates the culture of "Our America" (as Martí referred to Latin America) by placing it on a par with other cultures. ${ }^{3}$

The introduction of these perspectives is intended to lead to a rethinking of the nature of the Latin American essay as well as the region's cultural legacy in terms no longer exclusively tied to European values. That is to say, we must stop looking at Latin America from a European perspective. European or Western culture must not predominate.

Mestizos who are part European and part American, must not only learn to assimilate their European heritage but also their pre-Columbian American heritage. As long as the indigenous elements of the culture remain marginal or largely unacknowledged, their cultural identity remains incomplete.

The same point can be made with respect to the Afro-Latin American cultures of the continent. Until those elements that were most discriminated against at the time of the conquest and colonization are restored to a position of dignity in the cultural legacy of a nation, such a nation necessarily remains tied to the colonizer's prejudices and therefore cannot redeem itself fully from colonialism's negative weight. 


\section{NOTES}

1. Some well-known critics and academics are Peter Earle, Robert Mead Jr., Juan Loveluck, David Lagmanovich, Martin S. Staab, and Antonio Urrello.

2. Such studies increasingly problematize the concept of a literary canon based on a select number of texts considered representative of an "authentic" Latin American expression, conforming to the criteria of the dominant sectors of society that situate themselves within the Spanish heritage.

3. For Martí "Our America" refers to the concept of a Latin American for Latin Americans, a notion charged with important cultural implications whose contemporary political overtones are roughly equivalent to a rejection of U.S. and European domination in the area.

\section{REFERENCES}

Ainsa, Fernando. (1986) Identidad cultural de Iberoamérica en su narrativa. Madrid: Gredos.

Anderson Imbert, Enrique.(1965) Historia de la literatura hispanoamericana (5 $5^{\text {th }}$ ed.). (Vol. 1). México: Fondo de Cultura Económica.

Arguedas, José María. (1990). “No soy un aculturado." In Eve-Marie Fell (Ed.), El zorro de arriba y el zorro de abajo (256-58). Madrid: Tave.

Aullón de Haro, Pedro. (1987). "El ensayo filosófico actual." In Pedro Aullón de Haro (Ed.), Los géneros ensayísticos en el siglo XX(94-111). Madrid: Taurus.

Chachagua, Federico. (1998). "José Martí." In Tracy Chevalier (Ed.), Encyclopedia of the Essay (535-37). London: FitzRoy Dearborn.

Chanady, Amaryll Beatrice.(1994). "Latin American Imagined Communities and the Postmodern Challenge." In Amaryll Beatrice Chanady (Ed.), Latin American Identity and Constructions of Difference (ix-xvi). Minneapolis; London: U of Minnesota P.

De Grandis, Rita. (1997). "Incursiones en torno a hibridación: una propuesta para discusión de la mediación lingüística de Batjín a la mediación simbólica de García Canclini." Revista de Crítica Literaria Latinoamericana 23.46, 37-51.

Eley, Geoff. (1994). "Nations, Publics, and Political Cultures: Placing Habermas in the Nineteenth Century." In Nicholas B. Dirks, Geoff Eley \& Sherry B. Ortner (Eds.), Culture/power/history (297-335). NJ: Princeton UP. 
García Canclini, Nestor. (1990) Culturas hibridas: estrategias para entrar y salir de la modernidad. México: Grijalbo.

García-Pinto, Magdalena. (1986). "La identidad cultural de la vanguardia en Latinoamérica." In Saúl Yurkievich (Ed.), Identidad cultural de Iberoamérica en su literatura (102-15). Madrid: Alhambra.

Gates Jr., Henry Louis. (1987). "Authority, (White) Power and The (Black) Critic; It's All Greek To Me." Cultural Critique 7, 19-46.

Lagmanovich, David. "Hacia una teoría del ensayo hispanoamericano." In Isaac Lévy \& Juan Loveluck (Eds.), Simposio: El ensayo hispánico. Hispanic Studies 3, 17-28.

Martí, José. (1973) Nuestra América (2 ${ }^{\text {nd }}$ ed.). Barcelona: Ariel.

Mead Jr., Robert G. (1956) Breve historia del ensayo hispanoamericano. México: Ediciones de Andrea. cultura.

Sacoto, Antonio. (1981) El indio en el ensayo de la América española. Cuenca: Casa de la

Sarmiento, Domingo Faustino. (1991) Facundo. Civilización y barbarie ( $8^{\text {th }}$ ed.). México: Porrúa.

Vega, Inca Garcilaso de la. (1945) Comentarios reales de los Incas (2 Vols.).Buenos Aires: Emecé. 